See discussions, stats, and author profiles for this publication at: https://www.researchgate.net/publication/265176203

\title{
A preliminary assessment of the potential of using an acacia-biochar system for spent mine site rehabilitation
}

Article in Environmental Science and Pollution Research · January 2015

Dol: 10.1007/s11356-014-3451-1 · Source: PubMed

\section{CITATIONS}

26

8 authors, including:

Frédérique Reverchon

Institute of Ecology INECOL

138 PUBLICATIONS 294 CITATIONS

$$
\text { SEE PROFILE }
$$

Zhihong Xu

Griffith University

297 PUBLICATIONS 6,018 CITATIONS

SEE PROFILE
READS

244

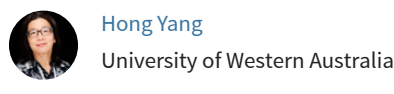

95 PUBLICATIONS 1,621 CITATIONS

SEE PROFILE

Chengrong Chen

Griffith University

180 PUBLICATIONS 3,269 CITATIONS

SEE PROFILE

Some of the authors of this publication are also working on these related projects:

Effects of woody plant range expansion on alpine soil microbial communities View project

ECOPICS: Belowground ecosystem services in plant communities along an elevational gradient in France and Mexico View project 
Received: 13 April 2014 / Accepted: 14 August 2014

(C) Springer-Verlag Berlin Heidelberg 2014

\begin{abstract}
Mining activities result in extensive soil degradation by removing the top soil, disturbing soil structure and altering microbial communities. Rehabilitation of spent mine sites through revegetation thus requires proper soil amendments. In this study, a pot trial was conducted to investigate the effects of a jarrah biochar on the growth and nutrient status of a native legume, Acacia tetragonophylla, grown in a mixture of topsoil and mine rejects. Two biochar application rates ( 37 and $74 \mathrm{tha}^{-1}$ ) and two types of biochar, namely nutrientenriched and non-enriched, were tested. We measured the soil $\mathrm{pH}$ and electrical conductivity, the carbon (C) and nitrogen (N) contents and $\mathrm{C}$ and $\mathrm{N}$ isotope composition $\left({ }^{13} \mathrm{C}\right.$ and
\end{abstract}

Responsible editor: Philippe Garrigues

F. Reverchon · J. Wang · Z. Xu

Environmental Futures Research Institute, School of Natural

Sciences, Griffith University, 170 Kessels Road, Nathan, QLD 4111,

Australia

C. Chen

Environmental Futures Research Institute, Griffith School of Environment, Griffith University, 170 Kessels Road, Nathan, QLD 4111, Australia

H. Yang $\cdot$ T. Y. Ho $\cdot$ D. Zhang

Centre for Energy (M473), The University of Western Australia, 35

Stirling Highway, Crawley, WA 6009, Australia

G. Yan

School of Plant Biology, Faculty of Science and The UWA Institute of Agriculture, The University of Western Australia, 35 Stirling Highway, Crawley, WA 6009, Australia

J. Wang

Key Laboratory for Subtropical Mountain Ecology, School of Geographical Sciences, Fujian Normal University, Fuzhou, China

F. Reverchon $(\square)$

Instituto de Ecología A.C., Xalapa, Veracruz, Mexico

e-mail: frederique.reverchon@inecol.mx $\delta^{15} \mathrm{~N}$ ) of soil and plants, the foliar phosphorus content and the growth and leaf biomass of the plants. Whilst no significant effect of biochar was observed on plant growth, biochar amendment affected soil properties and plant nutritional status. The highest rate of biochar application increased soil $\mathrm{pH}$, $\mathrm{C}$ content and $\mathrm{C} / \mathrm{N}$ ratio, and decreased soil $\delta^{13} \mathrm{C}$. Biochar application also enhanced photosynthetic $\mathrm{N}$ use efficiency, as showed by the increase in foliar $\mathrm{C} / \mathrm{N}$ ratio, and biological $\mathrm{N}$ fixation rates, as indicated by foliar $\delta^{15} \mathrm{~N}$. These positive effects were not observed when biochar was nutrientenriched due to the associated increase in soil $\mathrm{N}$. Revegetation of mine sites with acacia in combination with biochar amendment constitutes a plausible alternative to the wide use of $\mathrm{N}$ fertiliser through the supply of additional $\mathrm{N}$ to the system, even though other nutrients may be required in order to enhance plant early growth.

Keywords Acacia tetragonophylla $\cdot$ Mine rejects $\cdot$ Biological nitrogen fixation - Photosynthetic nitrogen use efficiency · Isotope composition

Mineral resources represent an important component of Australia's economy (Hajkowicz et al. 2011) but mining operations also cause intensive land degradation, including the removal of vegetation cover, loss of top soil and production of a large amount of mine wastes (Wong et al. 2003). Government regulations require offsetting activities and rehabilitation of the degraded areas after the mining activity has ceased. Because the most fertile layers of soils are usually removed during the mining process (Mench et al. 2003), postmining site revegetation is often challenging (Machado et al. 2013). The early stage of vegetation establishment is particularly crucial and requires good site preparation practices to 
maximise the chance of success of the revegetation process (Ruthrof et al. 2013; Hosseini Bai et al. 2014).

Site preparation practices have the potential to modify soil physicochemical properties (Hosseini Bai et al. 2012), thereby influencing nutrient availability for the establishing plants (Tan et al. 2005; Ibell et al. 2010). The application of soil amendments and fertilisers for example will facilitate the establishment of a broader range of vegetation (Bell 2001) by reducing competition for available water and nutrients (Ibell et al. 2013). Biochar, a carbon (C)-rich substrate and by-product of organic matter residue pyrolysis, is considered to be a promising soil amendment to enhance soil quality whilst reducing the global $\mathrm{C}$ footprint through soil $\mathrm{C}$ sequestration (Lehmann 2007; Barrow 2012). Biochar has been reported to improve soil structure and soil cation exchange capacity, as well as to retain plant available water due to its porous structure (Lehmann et al. 2003; Laird et al. 2010; Anderson et al. 2011). The application of biochar hence constitutes a site preparation method that could potentially increase the success of revegetation. However, some studies have shown that biochar only had a positive effect on plant growth when applied in conjunction with fertilisers (Rajkovich et al. 2012; Zhang et al. 2012), because high rates of biochar application can promote nitrogen $(\mathrm{N})$ immobilisation (Van Zwieten et al. 2010a; Bruun et al. 2012). Since degraded soils are likely to have limited $\mathrm{N}$ pools (Wong 2003), it is essential to ensure that this decrease in $\mathrm{N}$ availability following biochar application would not impair revegetation success. Combining biochar amendment with leguminous plants could help offset the potential decrease in $\mathrm{N}$ availability by ensuring an additional source of $\mathrm{N}$ input into the system (Forrester et al. 2005; Quilliam et al. 2013).

Little information is available regarding the combined effect of biochar and legumes for land rehabilitation. Biochar has previously been reported to increase biological $\mathrm{N}$ fixation (Rondon et al. 2006) through increases in nitrogenase activity (Quilliam et al. 2013), which would enhance the positive effects of legumes on N-poor soils. In addition, some legume species have been considered to be adequate species for the rehabilitation of degraded sites due to their high adaptability to harsh environmental conditions, including drought and low nutrient availability (Adams et al. 2010; Reverchon et al. 2012). The objective of this study was then to investigate the effect of biochar applied onto a mine site soil on the growth and nutrient status of early-stage Acacia tetragonophylla $\mathrm{F}$. Muell. (hereafter referred to as acacia, unless otherwise specified). Since several studies have noted an increase in plant growth following biochar application only when fertilisers were applied (Major et al. 2010; Rillig et al. 2010), we also tested whether saturating biochar in a nutrient solution prior to its application would affect soil and acacia characteristics during the early stage of plant establishment.

\section{Methods}

Biochar preparation

The jarrah wood biochar (Eucalyptus marginata Donn ex. Sm.) used in this study is the same as the jarrah biochar used in our previous work (Reverchon et al. 2014). The biochar was produced in an ANSAC HK indirectly fired kiln, at a maximum pyrolysis temperature of $700{ }^{\circ} \mathrm{C}$ and a residence time of 20 min under depleted oxygen environment. We then boiled $7 \mathrm{~kg}$ of biochar in an equivalent volume of water for $60 \mathrm{~min}$ in an unpressurized $20 \mathrm{~L}$ pot in order to remove most of the toxic phenols. After boiling, the biochar was drained and oven-dried for $48 \mathrm{~h}$ at $70^{\circ} \mathrm{C}$. Biochar characteristics were reported in Reverchon et al. (2014). Briefly, biochar Brunauer-Emmett-Teller (BET) surface area was $252 \mathrm{~m}^{2} \mathrm{~g}^{-1}$, its micropore area was $228 \mathrm{~m}^{2} \mathrm{~g}^{-1}$ and its average pore diameter was $2.14 \mathrm{~nm}$. Biochar $\mathrm{pH}$ measured in water (1:5 ratio) was 9.22 , its total $\mathrm{C}$ content was $74.7 \% \mathrm{C}$ and its total $\mathrm{N}$ content was $0.11 \% \mathrm{~N}$.

In addition, we saturated the boiled biochar in a nutrientrich solution (Hoagland's No. 2 Basal Salt Mixture, Sigma) prior to its application to test for the effect of fertiliser in combination with biochar application. Hoagland's solution is a widely used fertiliser that principally contains calcium and potassium nitrate, magnesium sulfate and ammonium phosphate. This additional treatment was also used in our previous study (Reverchon et al. 2014) which showed that the application of nutrient-enriched biochar enhanced nutrient availability and offset the competition between biochar and plants for nutrients.

The greenhouse pot trial consisted of four treatments: (1) application of $2.5 \%(w / w)$ biochar, which corresponds to a rate of $37 \mathrm{t} \mathrm{h}^{-1}$; (2) application of $2.5 \%(w / w)$ nutrientenriched biochar; (3) application of $5.0 \%(w / w)$ biochar, which corresponds to a rate of $74 \mathrm{t} \mathrm{h}^{-1}$ and (4) application of $5.0 \%(w / w)$ nutrient-enriched biochar. These biochar application rates were selected to be consistent with those used in our previous experiment (Reverchon et al. 2014). A control was included to the pot trial (no biochar application). Each treatment was replicated five times.

To investigate the feasibility of using biochar as a soil amendment for mine site rehabilitation, we used as a substrate a mixture of topsoil and mine rejects collected at BHP Billiton Iron Ore Pty Ltd's Mt Whaleback iron ore mine, located near Newman, in the Pilbara region of Western Australia. Soil and mine rejects were crushed and sieved to pass a 3-mm mechanical sieve and mixed homogeneously at a 1:1 (w/w) ratio. The different rates of biochar were added to $4.66 \mathrm{~kg}$ of the soil and 
mine reject mixture (hereafter referred to as soil), and mixed thoroughly before being placed in $4 \mathrm{~L}$ pots.

Seeds of acacia, a legume occurring naturally in the mining area where the soil and mine rejects were collected, were immersed in boiled water for $24 \mathrm{~h}$ to break the seed shell and favour germination. At the first sign of hypocotyl emergence, the seeds were transferred to $36-\mathrm{mm}$ peat pellets, in order to minimise the transplant shock. One seed was sown per pot at $20 \mathrm{~mm}$ depth. The seedlings were watered and soils were kept at $60 \%$ water holding capacity under the greenhouse conditions.

\section{Soil and plant analyses}

Soil and foliar samples were collected after 6 months for physical and chemical analyses. Soil samplers of $20 \times$ $250 \mathrm{~mm}$ were used to obtain the soil samples. For each pot, two samplers were inserted diametrically opposite to each other, at the midpoint between the centre and the edge of the pot, $30 \mathrm{~min}$ after watering. The cores were then mixed thoroughly to obtain one soil sample per pot. Approximately, $50 \mathrm{~g}$ of each soil sample was air-dried and ground to a fine powder using a Rocklabs ring grinder. We determined the total $\mathrm{C}$, total $\mathrm{N}$ and $\mathrm{C}$ and $\mathrm{N}$ isotope composition $\left(\delta^{13} \mathrm{C}\right.$ and $\delta^{15} \mathrm{~N}$, respectively) using mass spectrometry (GV Isoprime; Manchester, UK), as described in He et al. (2008). Soil pH and electrical conductivity (EC) were measured in water (1:5 ratio).

After 6 months, plants were measured for height and total number of leaves. Seedlings were still too small at 6 months for stem diameter to be accounted for. Only aboveground parameters were measured as plants were not harvested. One seedling in the $74 \mathrm{t} \mathrm{h}^{-1}$ application of non-enriched biochar treatment died during the experiment, decreasing our total plant number to 24 . In addition to plant measurements, ten fully expanded leaves were collected from each plant, ovendried at $60{ }^{\circ} \mathrm{C}$ to a constant weight and ground finely to measure the total $\mathrm{C}$, total $\mathrm{N}, \delta{ }^{13} \mathrm{C}$ and $\delta^{15} \mathrm{~N}$ using mass spectrometry. Total plant phosphorus (P) was determined following Kjeldahl digestion method (Taylor 2000). The total leaf dry mass was inferred by multiplying total number of leaves from the average weight of one leaf.

Statistical analyses

An analysis of variance (ANOVA) was carried out to determine the significant differences between the various treatments. The variables that were included in the ANOVA were soil $\mathrm{pH}$ and $\mathrm{EC}$, soil and plant total $\mathrm{C}$, total $\mathrm{N}, \mathrm{C} / \mathrm{N}$ ratio, $\delta^{13} \mathrm{C}$ and $\delta^{15} \mathrm{~N}$, plant total $\mathrm{P}$ and plant height and leaf biomass. Prior to the ANOVA, we used the Shapiro-Wilk test to verify variable normality and the Levene's test to verify homogeneity of variance. Variables that did not meet these assumptions (soil $\mathrm{pH}$, soil total $\mathrm{C}$ and total $\mathrm{N}$ and soil $\delta^{15} \mathrm{~N}$ ) were $\log$ - transformed. A Tukey post hoc test was used where the ANOVA was significant to compare means between treatments. All analyses were considered significant at $p<0.05$. Statistics were computed in SPSS version 21 (SPSS, Inc.).

\section{Results}

Effect of biochar on soil properties

The addition of biochar to the soil increased soil $\mathrm{pH}$ significantly compared to the control, regardless of the rate of application. On the other hand, biochar addition did not influence soil EC (Table 1). As expected, the total C content of the soil increased significantly with the rate of biochar addition, with a sevenfold increase in the soil total $\mathrm{C}$ when $74 \mathrm{t} \mathrm{ha}^{-1}$ of biochar was applied. The total $\mathrm{N}$ content of the soil was not significantly influenced by the biochar application rate but was affected by the nutrient-enrichment of biochar. At the highest rate of biochar application, the total $\mathrm{N}$ content of the soil was higher when biochar was nutrient-enriched than when non-enriched biochar was applied. Significant differences in the $\mathrm{C} / \mathrm{N}$ ratio of the soil were also found amongst treatments, the highest $\mathrm{C} / \mathrm{N}$ ratio being found when $74 \mathrm{t} \mathrm{ha}^{-1}$ of nonenriched biochar was applied, while the lowest $\mathrm{C} / \mathrm{N}$ ratio was found under the control conditions.

Biochar application also influenced soil $\delta^{13} \mathrm{C}$ and $\delta^{15} \mathrm{~N}$. Soil $\delta^{13} \mathrm{C}$ decreased significantly with the rate of non-enriched biochar addition (Table 1). In addition, soil $\delta^{13} \mathrm{C}$ after the application of enriched biochar was lower than that of the control. Biochar application also affected soil $\delta^{15} \mathrm{~N}$, the highest value for soil $\delta^{15} \mathrm{~N}$ being found when $74 \mathrm{t} \mathrm{ha}^{-1}$ of enriched biochar was added (Table 1).

Effect of biochar on acacia growth and foliar nutrient status

Biochar, regardless of the application rates and nutrient enrichment, did not have a significant effect on acacia height or leaf biomass (Table 2). However, significant differences were observed in acacia nutrient status amongst the treatments (Table 3). The acacia total $\mathrm{C}$ content was significantly higher when biochar was applied to the soil than under the control conditions, especially when biochar was not nutrientenriched. Whilst no significant effect of biochar was detected on acacia total $\mathrm{N}$ content, the acacia $\mathrm{C} / \mathrm{N}$ ratio was significantly higher when $37 \mathrm{t} \mathrm{ha}^{-1}$ of non-enriched biochar were added to the soil than under the control conditions. Differences were also observed in the acacia $\mathrm{P}$ status, with the plant total $\mathrm{P}$ being higher when $74 \mathrm{tha}^{-1}$ of enriched biochar was added to the soil than that when $37 \mathrm{t} \mathrm{ha}^{-1}$ of nutrient-enriched biochar was applied. 
t1.1 Table 1 Influence of biochar application on soil $\mathrm{pH}, \mathrm{EC}$, total $\mathrm{C}$, total $\mathrm{N}, \mathrm{C} / \mathrm{N}$ and $\mathrm{C}$ and $\mathrm{N}$ isotope composition $\left(\delta^{13} \mathrm{C}\right.$ and $\left.\delta^{15} \mathrm{~N}\right)$. Values represent means \pm standard errors

\begin{tabular}{lllllllll}
\cline { 2 - 7 } $\mathrm{t} 1.2$ & Treatment & $\mathrm{pH}$ & $\mathrm{EC}(\mu \mathrm{S})$ & Total C $\left(\mathrm{g} \mathrm{kg}^{-1}\right)$ & Total N $\left(\mathrm{g} \mathrm{kg}^{-1}\right)$ & $\mathrm{C} / \mathrm{N}$ & $\delta^{13} \mathrm{C}(\%)$ & $\delta^{15} \mathrm{~N}(\% \mathrm{o})$ \\
\cline { 2 - 8 } $\mathrm{t} 1.3$ & Control & $5.8 \pm 0.05 \mathrm{~b}$ & $244 \pm 46.6 \mathrm{a}$ & $3.74 \pm 0.11 \mathrm{c}$ & $0.28 \pm 0.006 \mathrm{ab}$ & $13.6 \pm 0.21 \mathrm{c}$ & $-19.1 \pm 0.12 \mathrm{a}$ & $3.63 \pm 0.07 \mathrm{ab}$ \\
$\mathrm{t} 1.4$ & $37 \mathrm{t} \mathrm{ha}^{-1}$ non-enriched biochar & $7.6 \pm 0.20 \mathrm{a}$ & $332 \pm 27.4 \mathrm{a}$ & $18.3 \pm 1.98 \mathrm{~b}$ & $0.25 \pm 0.035 \mathrm{ab}$ & $77.2 \pm 8.03 \mathrm{~b}$ & $-25.6 \pm 0.25 \mathrm{~b}$ & $2.38 \pm 0.40 \mathrm{~b}$ \\
$\mathrm{t} 1.5$ & $37 \mathrm{t} \mathrm{ha}^{-1}$ enriched biochar & $7.2 \pm 0.30 \mathrm{a}$ & $339 \pm 37.1 \mathrm{a}$ & $18.5 \pm 1.46 \mathrm{~b}$ & $0.27 \pm 0.026 \mathrm{ab}$ & $71.4 \pm 11.85 \mathrm{~b}$ & $-25.7 \pm 0.27 \mathrm{bc}$ & $3.59 \pm 0.23 \mathrm{ab}$ \\
$\mathrm{t} 1.6$ & $74 \mathrm{t} \mathrm{ha}^{-1}$ non-enriched biochar & $7.8 \pm 0.13 \mathrm{a}$ & $398 \pm 66.8 \mathrm{a}$ & $31.8 \pm 1.38 \mathrm{a}$ & $0.23 \pm 0.022 \mathrm{~b}$ & $149.4 \pm 18.90 \mathrm{a}$ & $-26.6 \pm 0.06 \mathrm{c}$ & $5.22 \pm 1.10 \mathrm{ab}$ \\
$\mathrm{t} 1.7$ & $74 \mathrm{t} \mathrm{ha}^{-1}$ enriched biochar & $7.0 \pm 0.24 \mathrm{a}$ & $228 \pm 42.4 \mathrm{a}$ & $30.4 \pm 4.70 \mathrm{a}$ & $0.34 \pm 0.012 \mathrm{a}$ & $90.1 \pm 15.83 \mathrm{~b}$ & $-26.2 \pm 0.12 \mathrm{bc}$ & $6.81 \pm 1.47 \mathrm{a}$
\end{tabular}

Different letters within columns represent significant differences (Tukey post hoc test, $p<0.05$ )

t2.1 Table 2 Influence of biochar application on growth variables of Acacia tetragonophylla. Values represent means \pm standard errors

\begin{tabular}{llll} 
t2.2 & Treatment & $\begin{array}{l}\text { Plant height } \\
(\mathrm{cm})\end{array}$ & $\begin{array}{l}\text { Total leaf } \\
\text { biomass }(\mathrm{g})\end{array}$ \\
\cline { 2 - 4 } $\mathrm{t} 2.3$ & Control & $31.4 \pm 3.0 \mathrm{a}$ & $2.7 \pm 0.5 \mathrm{a}$ \\
$\mathrm{t} 2.4$ & $37 \mathrm{t} \mathrm{ha}^{-1}$ non-enriched biochar & $33.0 \pm 4.2 \mathrm{a}$ & $3.6 \pm 0.7 \mathrm{a}$ \\
$\mathrm{t} 2.5$ & $37 \mathrm{t} \mathrm{ha}^{-1}$ enriched biochar & $33.2 \pm 4.0 \mathrm{a}$ & $4.5 \pm 0.7 \mathrm{a}$ \\
$\mathrm{t} 2.6$ & $74 \mathrm{t} \mathrm{ha}^{-1}$ non-enriched biochar & $33.5 \pm 4.9 \mathrm{a}$ & $3.3 \pm 0.5 \mathrm{a}$ \\
$\mathrm{t} 2.7$ & $74 \mathrm{t} \mathrm{ha}^{-1}$ enriched biochar & $37.0 \pm 4.4 \mathrm{a}$ & $5.1 \pm 1.0 \mathrm{a}$
\end{tabular}

No significant differences were found amongst treatments, as shown by the same letters within columns (Tukey post hoc test, $p<0.05$ )
(2010) and Luo et al. (2011) also described sharp increases in soil $\mathrm{pH}$ following biochar application to acidic soils (initial soil $\mathrm{pH}=5.5$ and 3.7 , respectively). Van Zwieten et al. (2010b) attributed the liming effect of biochar to the presence of carbonate complexes in the biochar, hence promoting its high acid neutralising ability. Soil $\mathrm{pH}$ has been reported to be a critical factor controlling revegetation success (Córdova et al. 2011), and biochar could be used as a liming amendment for enhancing nutrient availability and plant survival during the early stage of vegetation establishment. In addition to increasing the soil $\mathrm{pH}$, biochar is usually reported to increase soil EC (Atkinson et al. 2010; Fellet et al. 2011; Smider and Singh 2014) through the input of wood ash containing readily soluble cations (Soinne et al. 2014). The lack of effect of biochar on soil EC in this study may be explained by the fact that biochar was boiled before being mixed with the soil, which could have led to cation loss.

The increase in the total $\mathrm{C}$ and $\mathrm{C} / \mathrm{N}$ of the soil and the decrease in soil $\delta^{13} \mathrm{C}$ with the application of increasing rates of biochar are most likely due to the intrinsic properties of biochar itself rather than to changes in the soil microbial activity (Ibell et al. 2010). Biochar is a C-rich product with a lower $\delta^{13} \mathrm{C}(-26.2 \%$ for the biochar used in this study) than that of the soil under study. The initial $\mathrm{C}$ content of the soil mixture used in this study was particularly low, and biochar addition could constitute a means to restore some of the lost soil structure and stability (Atkinson et al. 2010), thereby favouring the revegetation process.

Biochar did not affect the $\mathrm{N}$ content and $\delta^{15} \mathrm{~N}$ of the soil, except when nutrient-enriched at the highest rate of application. The lack of effect of biochar on the soil $\mathrm{N}$ pools (Reverchon et al. 2014) or the decrease in $\mathrm{N}$ availability following biochar application in the short-term (Nelissen et al. 2012; Rajkovich et al. 2012) have prompted the recommendation of using biochar in combination with a fertiliser (Steiner et al. 2008; Van Zwieten et al. 2010a). This is particularly critical where nutrient retention could hamper plant early establishment on degraded soils that require stabilisation by revegetation (Beesley et al. 2011). 
t3.1 Table 3 Influence of biochar application on foliar nutrient status and $\mathrm{C}$ and $\mathrm{N}$ isotope composition $\left(\delta^{13} \mathrm{C}\right.$ and $\left.\delta^{15} \mathrm{~N}\right)$ of Acacia tetragonophylla. Values represent means \pm standard errors

\begin{tabular}{|c|c|c|c|c|c|c|c|}
\hline $\mathrm{t} 3.2$ & Treatment & Total C $\left(\mathrm{g} \mathrm{kg}^{-1}\right)$ & Total $\mathrm{N}\left(\mathrm{g} \mathrm{kg}^{-1}\right)$ & $\mathrm{C} / \mathrm{N}$ & Total $\mathrm{P}\left(\mathrm{g} \mathrm{kg}^{-1}\right)$ & $\delta^{13} \mathrm{C}(\%)$ & $\delta^{15} \mathrm{~N}(\%)$ \\
\hline $\mathrm{t} 3.3$ & Control & $437 \pm 4.0 \mathrm{c}$ & $21.6 \pm 1.61 \mathrm{a}$ & $20.7 \pm 1.5 b$ & $0.74 \pm 0.07 \mathrm{ab}$ & $-32.31 \pm 0.34 \mathrm{a}$ & $4.56 \pm 0.60 \mathrm{ab}$ \\
\hline $\mathrm{t} 3.4$ & $37 \mathrm{t} \mathrm{ha}^{-1}$ non-enriched biochar & $464 \pm 2.4 \mathrm{a}$ & $17.4 \pm 1.45 \mathrm{a}$ & $27.5 \pm 2.4 \mathrm{a}$ & $0.64 \pm 0.08 \mathrm{ab}$ & $-32.93 \pm 0.18 \mathrm{a}$ & $1.69 \pm 1.21 \mathrm{bc}$ \\
\hline $\mathrm{t} 3.5$ & $37 \mathrm{t} \mathrm{ha}^{-1}$ enriched biochar & $446 \pm 5.6 \mathrm{abc}$ & $19.7 \pm 1.05 \mathrm{a}$ & $23.0 \pm 1.5 \mathrm{ab}$ & $0.62 \pm 0.47 \mathrm{~b}$ & $-32.81 \pm 0.14 \mathrm{a}$ & $6.52 \pm 1.39 \mathrm{a}$ \\
\hline $\mathrm{t} 3.6$ & $74 \mathrm{t} \mathrm{ha}^{-1}$ non-enriched biochar & $459 \pm 4.0 \mathrm{ab}$ & $20.7 \pm 0.69 \mathrm{a}$ & $22.3 \pm 0.8 \mathrm{ab}$ & $0.76 \pm 0.05 \mathrm{ab}$ & $-33.25 \pm 0.16 \mathrm{a}$ & $0.31 \pm 0.63 \mathrm{c}$ \\
\hline $\mathrm{t} 3.7$ & $74 \mathrm{t} \mathrm{ha}^{-1}$ enriched biochar & $444 \pm 5.3 b c$ & $22.5 \pm 1.16 \mathrm{a}$ & $19.9 \pm 1.0 \mathrm{~b}$ & $1.07 \pm 0.18 \mathrm{a}$ & $-33.19 \pm 0.33 \mathrm{a}$ & $7.95 \pm 0.57 \mathrm{a}$ \\
\hline
\end{tabular}

Different letters within columns represent significant differences (Tukey post hoc test, $p<0.05$ )

\section{Effect of biochar on foliar nutrient status of acacia}

Although biochar application did not have any significant effect on acacia height or leaf biomass, it positively influenced acacia leaf $\mathrm{C}$ and $\mathrm{C} / \mathrm{N}$ ratio, especially when non-enriched biochar was applied. The $\mathrm{C} / \mathrm{N}$ ratio indicates the $\mathrm{C}$ and $\mathrm{N}$ relationship in plants and is therefore an appraisal of photosynthetic $\mathrm{N}$ use efficiency (Mohale et al. 2014). This enhancement of $\mathrm{N}$ use efficiency was probably not associated with an increase in photosynthetic capacity, as no variations in leaf $\delta^{13} \mathrm{C}$ were observed after biochar addition. Foliar $\delta^{13} \mathrm{C}$ can be related to plant productivity through photosynthesis but also through water use efficiency (Farquhar and Richards 1984; $\mathrm{Xu}$ et al. 2000). The constant water holding capacity at which the pots were kept is hence likely to have hindered any effect of biochar on water use efficiency by acacias. The addition of nutrient-enriched biochar cancelled the increase in the photosynthetic $\mathrm{N}$ use efficiency observed through the foliar $\mathrm{C} / \mathrm{N}$ ratio. The highest application rate of nutrient-enriched biochar constituted a significant additional supply of $\mathrm{N}$ as shown by the subsequent increase in the $\mathrm{N}$ content of the soil, which could have reduced the plant $\mathrm{N}$ use efficiency.

The additional $\mathrm{N}$ input into the system by enriching biochar in a fertiliser solution also affected leaf $\delta^{15} \mathrm{~N}$. Plant $\delta^{15} \mathrm{~N}$ indicates the conditions of $\mathrm{N}$ nutrition where and when the plants were grown (Reverchon et al. 2014) and, as such, is usually considered as an estimate of soil $\delta^{15} \mathrm{~N}$ at the time of growth (Xu et al. 2003; Ibell et al. 2013). In legumes, however, leaf $\delta^{15} \mathrm{~N}$ is an indication of biological $\mathrm{N}$ fixation (BNF) (Hosseini Bai et al. 2013) and has been frequently used in the so-called ${ }^{15} \mathrm{~N}$ natural abundance method to estimate the percentage of $\mathrm{N}$ derived from the atmosphere (Shearer and Kohl 1986). A reduction in foliar $\delta^{15} \mathrm{~N}$ corresponds to a relative increment in BNF, although reference plants are necessary in order to assess the exact quantity of $\mathrm{N}$ fixed through BNF. In this study, the application rate of non-enriched biochar decreased leaf $\delta^{15} \mathrm{~N}$, thereby increasing BNF rates. The coupled increase in $\mathrm{C} / \mathrm{N}$ values and decrease in $\delta^{15} \mathrm{~N}$ values (Fig. 1) suggest that the photosynthetic $\mathrm{N}$ use efficiency was enhanced by higher levels of BNF (Mohale et al. 2014). Nevertheless, the increment in BNF rates was not observed when nutrient- enriched biochar was added (Fig. 1). Previous findings have shown that BNF increases under biochar application (Rondon et al. 2006) and decreases under fertiliser application (Ledgard and Steele 1992; Vessey and Waterer 1992). The BNF is a costly biological process that can promote plant survival under N-limited conditions (Hosseini Bai et al. 2013) but will not be needed when $\mathrm{N}$ supplies are sufficient for plant growth. In conclusion, whilst fertiliser addition in combination with biochar application may be required in order to guarantee plant growth in the early stage of plant establishment under a broad range of conditions, it may be unnecessary where acacias are to be used, which would hence decrease the associated risk of further environmental pollution (Graham and Vance 2000). Although the use of fertiliser could also benefit plant growth by increasing the foliar contents of other nutrients, especially $\mathrm{P}$, in this study, we did not observe differences in foliar $\mathrm{P}$ when comparing non-enriched $v s$ enriched biochar.

\section{Recommendations for mining soil rehabilitation}

In this study, we found that acacia combined with jarrah biochar could offer a plausible alternative for mining site rehabilitation. Although in this case biochar addition did not significantly improve plant growth, it enhanced BNF rates, thereby leading to the additional supply of $\mathrm{N}$ to the soil by litter fall. The additional input of $\mathrm{N}$ to the substrate may be crucial for the success of early establishment of plants on mine

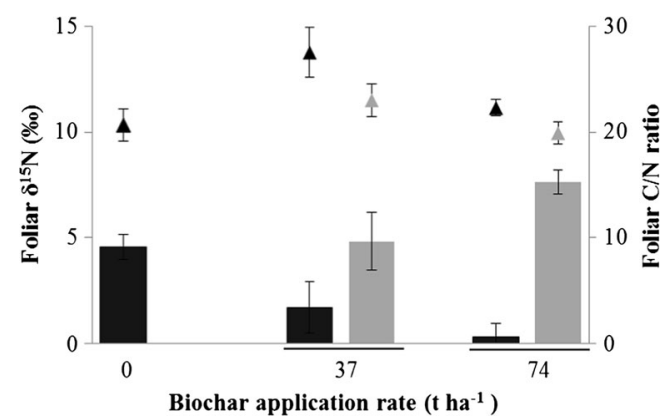

Fig. 1 Effect of biochar application on foliar $\delta^{15} \mathrm{~N}$ (bars) and $\mathrm{C} / \mathrm{N}$ ratio (triangles) of Acacia tetragonophylla. Non-enriched biochar application is represented in black and nutrient-enriched biochar in gray. Values represent means \pm standard errors 
rejects. Novak et al. (2009) suggested that biochar production could be adapted to fit the specific characteristics of a degraded soil in order to maximise its benefits. Wood biochars formed through slow pyrolysis were recommended by Jien and Wang (2013) as an efficient acid-neutralizing material for highly degraded soils and as a way to improve soil structure and erosion resistance through the increase aggregate stability. Some considerations should also be given to the specific mechanisms of contaminant-biochar retention and release over time to ensure that the success of revegetation coincides with an effective management of environmental pollution (Beesley et al. 2011). Finally, the impact of biochar on beneficial soil microorganisms should be further investigated, especially when the plants used for revegetation are known to form symbiotic associations. This is the case for acacias, which form associations with N-fixing bacteria and with mycorrhizal fungi. In the present trial, plants were not harvested in order to continue investigating longer-term effects of biochar on acacia growth. Therefore, we could not obtain data regarding the response of root biomass and rhizospheric microorganisms to biochar addition. Nevertheless, there are indications that biochar application has a positive short-term effect on N-fixing bacteria (Quilliam et al. 2013) and on arbuscular mycorrhizal fungi activity (Warnock et al. 2007). These positive effects of biochar on soil microorganisms still need to be assessed in the long-term and in field studies. Nevertheless, the potential of using biochar associated with acacias for revegetation of spent mine sites seems promising.

Acknowledgments Financial support was provided by the Australian Research Council under the ARC Linkage Project Scheme (ARC Linkage Project LP100200135), with BHP Billiton Iron Ore Pty Ltd. and Ansac Pty Ltd. as the partner organisations. The authors would like to thank Huajie Yu, Yiwei Xu, Bill Piasini, Haito Zhao and Rene Diocares for their technical assistance, and Dr Shahla Hosseini-Bai for her help in processing the samples and her valuable comments on previous drafts of this manuscript.

\section{References}

Adams MA, Simon J, Pfautsch S (2010) Woody legumes: a (re)view from the South. Tree Physiol 30:1072-1082

Anderson CR, Condron LM, Clough TJ, Fiers M, Stewart A, Hill RA, Sherlock RR (2011) Biochar induced soil microbial community change: Implications for biogeochemical cycling of carbon, nitrogen and phosphorus. Pedobiologia 54:309-320

Atkinson CJ, Fitzgerald JD, Hipps NA (2010) Potential mechanisms for achieving agricultural benefits from biochar application to temperate soils: a review. Plant Soil 337:1-18

Barrow CJ (2012) Biochar: Potential for countering land degradation and for improving agriculture. Appl Geogr 34:21-28

Beesley L, Moreno-Jiménez E, Gomez-Eyles JL (2010) Effects of biochar and greenwaste compost amendments on mobility, bioavailability and toxicity of inorganic and organic contaminants in a multi-element polluted soil. Environ Poll 158: 2282-2287
Beesley L, Moreno-Jiménez E, Gomez-Eyles JL, Harris E, Robinson B, Sizmur T (2011) A review of biochars' potential role in the remediation, revegetation and restoration of contaminated soils. Environ Poll 159:3269-3282

Bell LC (2001) Establishment of native ecosystems after miningAustralian experience across diverse biogeographic zones. Ecol Eng 17:179-186

Bruun EW, Ambus P, Egsgaard H, Hauggaard-Nielsen H (2012) Effects of slow and fast pyrolysis biochar on soil $\mathrm{C}$ and $\mathrm{N}$ turnover dynamics. Soil Biol Biochem 46:73-79

Córdova S, Neaman A, González I, Ginocchio R, Fine P (2011) The effect of lime and compost amendments on the potential for the revegetation of metal-polluted, acidic soils. Geoderma 166:135-144

Farquhar G, Richards R (1984) Isotopic composition of plant carbon correlates with water-use efficiency of wheat genotypes. Aust $\mathrm{J}$ Plant Physiol 11:539-552

Fellet G, Marchiol L, Delle Vedove G, Peressotti A (2011) Application of biochar on mine tailings: Effects and perspectives for land reclamation. Chemosphere 83:1262-1267

Forrester DI, Bauhus J, Cowie AL (2005) Nutrient cycling in a mixed species plantation of Eucalyptus globulus and Acacia mearnsii. Can J For Res 35:2942-2950

Graham PH, Vance CP (2000) Nitrogen fixation in perspective: an overview of research and extension needs. Field Crop Res 65:93106

Hajkowicz SA, Heyenga S, Moffat K (2011) The relationship between mining and socio-economic well being in Australia's regions. Resour Policy 36:30-38

He Y, Xu Z, Chen C, Burton J, Ma Q, Ge Y, Xu J (2008) Using light fraction and macroaggregate associated organic matters as early indicators for management-induced changes in soil chemical and biological properties in adjacent native and plantation forests of subtropical Australia. Geoderma 147:116-125

Hosseini Bai S, Blumfield TJ, Xu ZH, Chen CR, Wild C (2012) Soil organic matter dynamics and nitrogen availability in response to site preparation and management during revegetation in tropical Central Queensland, Australia. J Soil Sediments 12:386-395

Hosseini Bai S, Sun FF, Xu ZH, Blumfield TJ (2013) Ecophysiological status of different growth stage of understorey Acacia leiocalyx and Acacia disparrima in an Australian dry sclerophyll forest subjected to prescribed burning. J Soil Sediments 13:1378-1385

Hosseini Bai S, Blumfield TJ, Reverchon F (2014) The impact of mulch type on soil organic carbon and nitrogen pools in a sloping site. Biol Fertil Soils 50:37-44

Ibell PT, Xu ZH, Blumfield TJ (2010) Effects of weed control and fertilization on soil carbon and nutrient pools in an exotic pine plantation of subtropical Australia. J Soils Sediments 10:1027-1038

Ibell PT, Xu ZH, Blumfield TJ (2013) The influence of weed control on foliar $\delta^{15} \mathrm{~N}, \delta^{13} \mathrm{C}$ and tree growth in an 8 year-old exotic pine plantation of subtropical Australia. Plant Soil 369:199-217

Jien SH, Wang CS (2013) Effects of biochar on soil properties and erosion potential in a highly weathered soil. Catena 110: 225-233

Laird DA, Fleming P, Davis DD, Horton R, Wang B, Karlen DL (2010) Impact of biochar amendments on the quality of a typical Midwestern agricultural soil. Geoderma 158:443-449

Ledgard SF, Steele KW (1992) Biological nitrogen fixation in mixed legume/grass pastures. Plant Soil 141:137-153

Lehmann J (2007) Bio-energy in the black. Front Ecol Environ 5:381387

Lehmann J, da Silva JP, Steiner C, Nehls T, Zech W, Glaser B (2003) Nutrient availability and leaching in an archaeological Anthrosol and a Ferralsol of the Central Amazon basin: Fertilizer manure and charcoal amendments. Plant Soil 249:343-357

Luo Y, Durenkamp M, De Nobili M, Lin Q, Brookes PC (2011) Short term soil priming effects and the mineralisation of biochar following 
its incorporation to soils of different $\mathrm{pH}$. Soil Biol Biochem 43: 2304-2314

Machado NADM, Leite MGP, Figueiredo MA, Kozovits AR (2013) Growing Eremanthus erythropappus in crushed laterite: a promising alternative to topsoil for bauxite-mine revegetation. J Environ Manage 129:149-156

Major J, Rondon M, Molina D, Riba SJ, Lehmann J (2010) Maize yield and nutrition during 4 years after biochar application to a Columbian savanna oxisol. Plant Soil 333:117-128

Mench M, Bussiere S, Vangronsveld J, Manceau A (2003) Progress in remediation and revegetation of the barren Jales gold mine spoil after in-situ treatments. Plant Soil 249:187-202

Mohale KC, Belane AK, Dakora FD (2014) Symbiotic N nutrition, C assimilation, and plant water use efficiency in Bambara groundnut (Vigna subterranea L. Verdc) grown in farmers' fields in South Africa, measured using ${ }^{15} \mathrm{~N}$ and ${ }^{13} \mathrm{C}$ natural abundance. Biol Fertil Soils 50:307-319

Nelissen V, Rütting T, Huygens D, Staelens J, Ruysschaert G, Boeckx P (2012) Maize biochars accelerate short-term soil nitrogen dynamics in a loamy sand soil. Soil Biol Biochem 55:20-27

Novak JM, Lima I, Gaskin JW, Steiner C, Das KC, Ahmedna M, Rehrah D, Watts DW, Busscher WJ, Schomberg H (2009) Characterization of designer biochar produced at different temperatures and their effects on a loamy sand. Ann Environ Sci 3:195-206

Quilliam RS, DeLuca TH, Jones DL (2013) Biochar application reduces nodulation but increases nitrogenase activity in clover. Plant Soil 366:83-92

Rajkovich S, Enders A, Hanley K, Hyland C, Zimmerman AR, Lehmann $\mathrm{J}$ (2012) Corn growth and nitrogen nutrition after additions of biochars with varying properties to a temperate soil. Biol Fertil Soils 48:271-284

Reverchon F, Xu ZH, Blumfield TJ, Chen CR, Abdullah KM (2012) Impact of global climate change and fire on the occurrence and function of understorey legumes in forest ecosystems. J Soil Sediments 12:150-160

Reverchon F, Flicker RC, Yang H, Yan G, Xu ZH, Chen CR, Hosseini Bai S, Zhang D (2014) Changes in $\delta^{15} \mathrm{~N}$ in a soil-plant system under different biochar feedstocks and application rates. Biol Fertil Soils $50: 275-283$

Rillig MC, Wagner M, Salem M, Antunes PM, George C, Ramke HG (2010) Material derived from hydrothermal carbonization: Effects on plant growth and arbuscular mycorrhiza. Appl Soil Ecol 45:273287

Rondon MA, Lehmann J, Ramírez J, Hurtado M (2006) Biological nitrogen fixation by common beans (Phaseolus vulgaris L.) increases with bio-char additions. Biol Fertil Soils 43:699-708

Ruthrof KX, Fontaine JB, Buizer M, Matusick G, McHenry MP, Hardy GESJ (2013) Linking restoration outcomes with mechanism: the role of site preparation, fertilisation and revegetation timing relative to soil density and water content. Plant Ecol 214:987-998

Shearer G, Kohl DH (1986) $\mathrm{N}_{2}$ fixation in field settings: Estimations based on natural ${ }^{15} \mathrm{~N}$ abundance. Aust J Plant Physiol 13:699-756

Smider B, Singh B (2014) Agronomic performance of a high ash biochar in two contrasting soils. Agr Ecosyst Environ. In press

Soinne H, Hovi J, Tammeorg P, Turtola E (2014) Effect of biochar on phosphorus sorption and clay soil aggregate stability. Geoderma 219:162-167

Steiner C, Das KC, Garcia M, Förster B, Zech W (2008) Charcoal and smoke extract stimulate the soil microbial community in a highly weathered xanthic ferralsol. Pedobiologia 51:359-366

Tan X, Chang SX, Kabzems R (2005) Effects of soil compaction and forest floor removal on soil microbial properties and $\mathrm{N}$ transformations in a boreal forest long-term soil productivity study. For Ecol Manage 217:158-170

Taylor MD (2000) Determination of total phosphorus in soil using simple Kjeldahl digestion. Commun Soil Sci Plant Anal 31:2665-2670

Van Zwieten L, Kimber S, Downie A, Morris S, Petty S, Rust J, Chan KY (2010a) A glasshouse study on the interaction of low mineral ash biochar with nitrogen in a sandy soil. Austr J Soil Res 48:569-576

Van Zwieten L, Kimber S, Morris S, Chan K, Downie A, Rust J, Joseph S, Cowie A (2010b) Effects of biochar from slow pyrolysis of paper mill waste on agronomic performance and soil fertility. Plant Soil 327:235-246

Vessey JK, Waterer J (1992) In search of the mechanism of nitrate inhibition of nitrogenase activity in legume nodules: Recent developments. Physiol Plantarum 84:171-176

Warnock DD, Lehmann J, Kuyper TW, Rillig MC (2007) Mycorrhizal responses to biochar in soil - Concepts and mechanisms. Plant Soil 300:9-20

Wong MH (2003) Ecological restoration of mine degraded soils, with emphasis on metal contaminated soils. Chemosphere 50:775-780

Xu ZH, Saffigna PG, Farquhar GD, Simpson JA, Haines RJ, Walker S, Osborne DO, Guinto D (2000) Carbon isotope discrimination and oxygen isotope composition in clones of the $\mathrm{F}(1)$ hybrid between slash pine and Caribbean pine in relation to tree growth, water-use efficiency and foliar nutrient concentration. Tree Physiol 20:12091217

Xu ZH, Prasolova NV, Lundkvist K, Beadle C, Leaman T (2003) Genetic variation in branchlet carbon and nitrogen isotope composition and nutrient concentration of 11-year-old hoop pine families in relation to tree growth in subtropical Australia. For Ecol Manage 186:359371

Zhang A, Liu Y, Pan G, Hussain Q, Li L, Zheng J, Zhang X (2012) Effect of biochar amendment on maize yield and greenhouse gas emissions from a soil organic carbon poor calcareous loamy soil from Central China Plain. Plant Soil 351:263-275 